\title{
New record of Thysanorea papuana from India
}

\author{
Pratibha $\mathbf{J}^{1}$ and Prabhugaonkar $\mathrm{A}^{2}$ \\ ${ }^{1}$ Department of Botany, Goa University, Goa 403206, India. Email: jalmipratibha@ rediffmail.com \\ ${ }^{2}$ Botanical survey of India, ERC Shillong, Meghalaya-793003, India
}

Pratibha J and Prabhugaonkar A 2015 - New record of Thysanorea papuana from India. Mycosphere 6(4), 480-485, Doi 10.5943/mycosphere/6/4/9

\begin{abstract}
Studies on litter degrading microfungi from forests of Western Ghats is discovering many fungi, some of which are very rare in nature. This paper illustrates Thysanorea papuana and is the first report of its occurrence in India, extending distribution from its originally described locality of Papua New Guinea. The genus Thysanorea is monotypic and is reported for the first time from India. The identity of the fungus is confirmed based on morphological characters and molecular phylogeny of ITS and LSU regions. Isolation of this fungus is an important distributional record for this rare fungal species.
\end{abstract}

Key words - Biodiversity - Western Ghats

\section{Introduction}

Many fungi were collected during studies on litter degrading microfungi from forests of Goa. This paper illustrates Thysanorea papuana (Aptroot) Arzanlou, W. Gams \& Crous and is the first report of its occurrence in India, extending the distribution from originally described locality of Papua New Guinea. The species, which belong to a monotypic genus, is described and illustrated with micro-photographs. The culture obtained from single spore isolation was used to generate ITS and LSU sequence-data.

\section{Materials \& Methods}

Thysanorea papuana was isolated from an unidentified dead twig from the forests of Valpoi, Goa, India. Samples were taken to the laboratory in zip lock polythene bags, and examined under a stereoscope. The fungus was picked up with a sterile needle, mounted in lactophenol and observed under a light microscope. The culture was obtained by single spore isolation (Choi et al. 1999). A drop of sterile distilled water was placed on a flame-sterilized slide and the sporulating fungal mass was aseptically transferred into the water and teased with flame-sterilised needle in order to obtain a spore suspension. The suspension was spread onto malt extract agar (MEA) plates with antibiotics incorporated $(20 \mathrm{mg} / \mathrm{L}$ each streptomycin and penicillin). The developing colonies, arising from individual conidia, were aseptically transferred onto fresh plates. After confirming the identity of the culture, molecular sequencing was done at Rajiv Gandhi Centre for Biotechnology, Thiruvananthapuram, Kerala, India.

\section{DNA isolation and PCR analysis}

Fresh fungal mycelia $(20 \mathrm{mg})$ were scraped from the growing culture incubated at $28^{\circ} \mathrm{C}$ for 7 days. DNA isolation and PCR analysis was done according to Prabhugaonkar \& Bhat (2011). The 


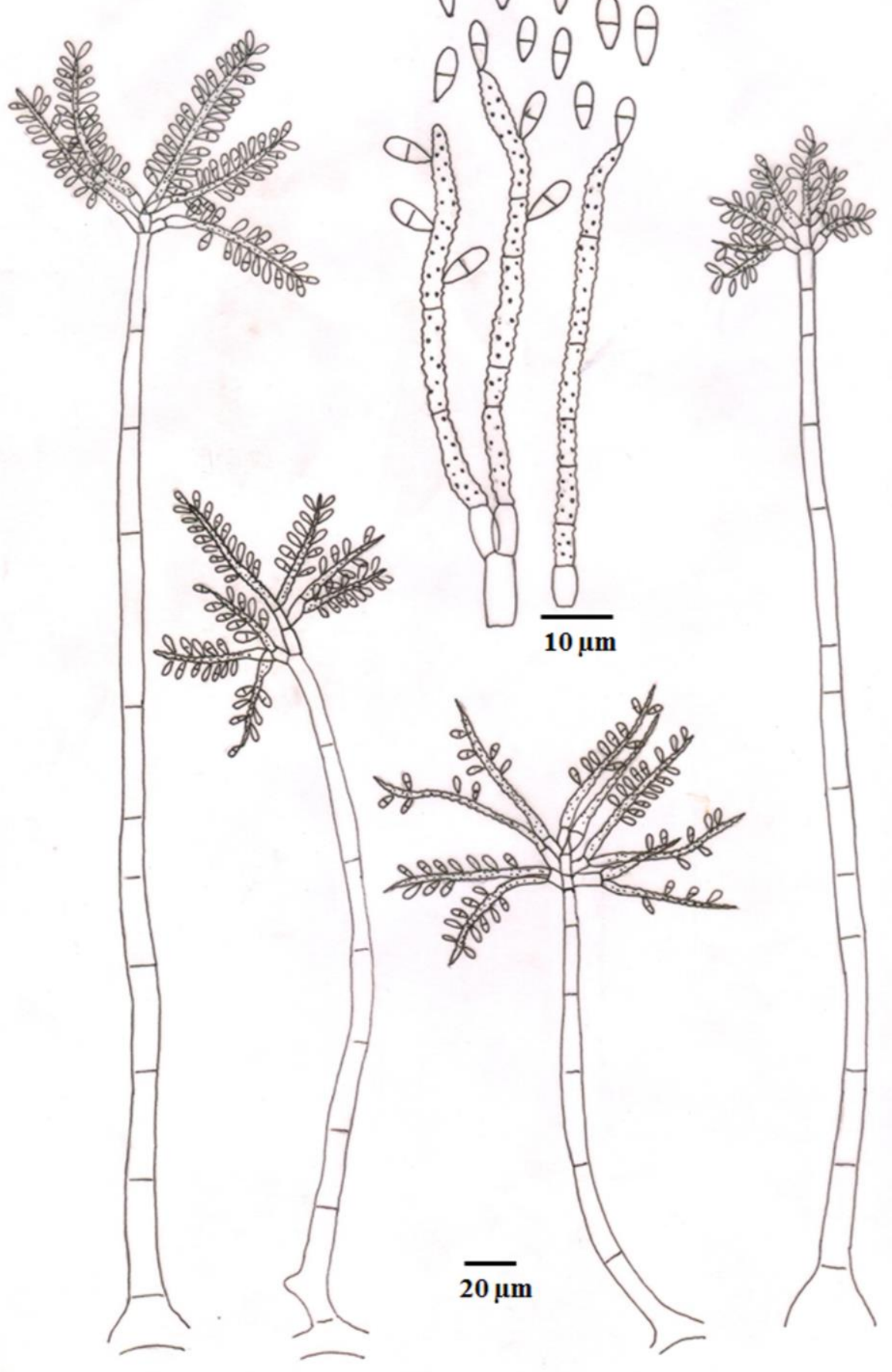

Fig. 1 - Thysanorea papuana, conidiophores, conidiogenous cells and conidia.

5.8S nuclear ribosomal gene with the two flanking internal transcribed spacers (ITS) and 28S nrDNA sequence (LSU) genes were amplified and sequenced using the primer pairs ITS-1F + ITS4R (White et al. 1990) and LR5 + LROR (Crous et al. 2009), respectively. The sequence quality was checked using Sequence Scanner Software v1 (Applied Biosystems). Sequence alignment and required editing of the obtained sequences were carried out using Geneious Pro v5.1 (Drummond et al. 2010). 

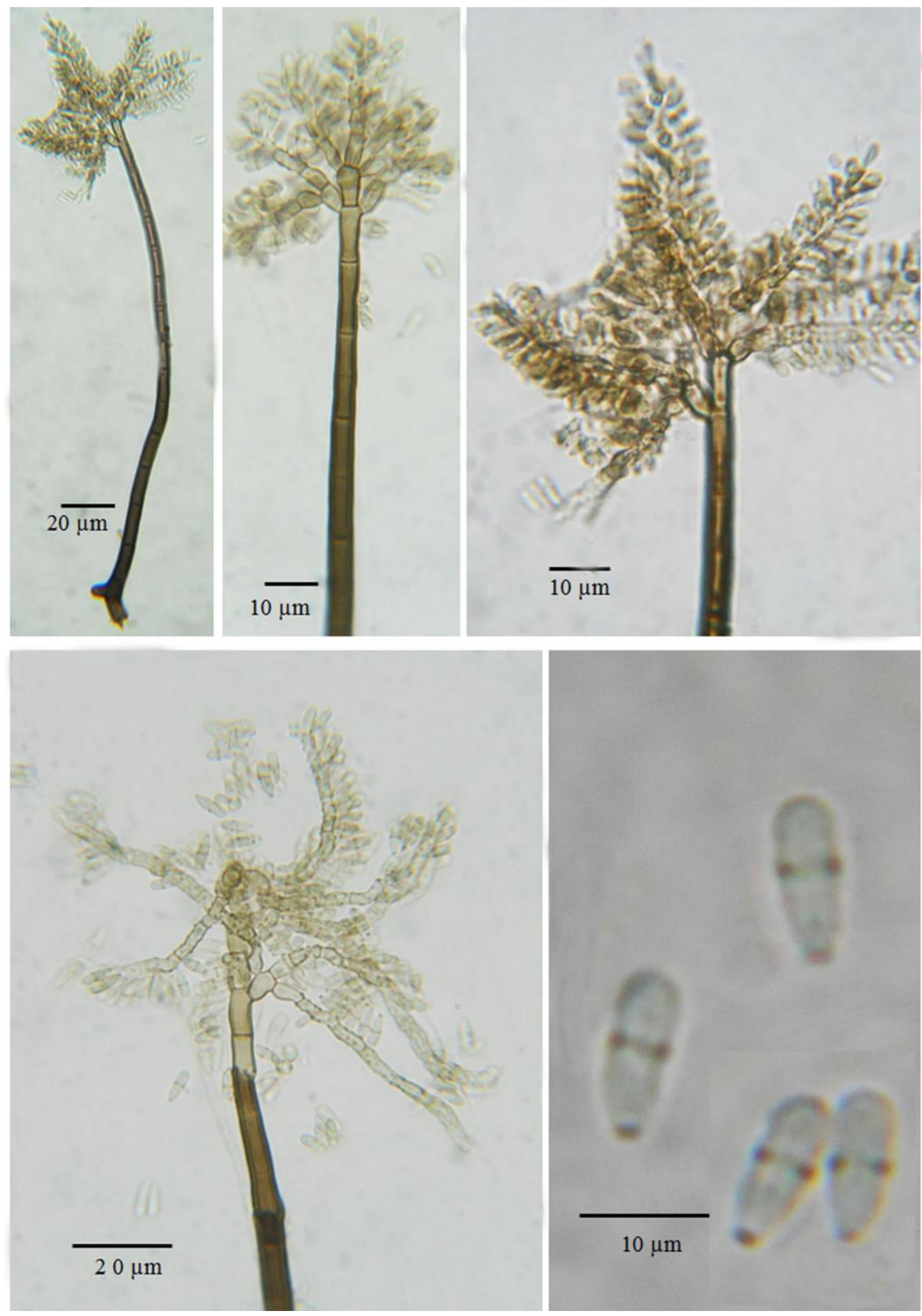

Fig. 2 - Thysanorea papuana, conidiophores, conidiogenous cells and conidia.

\section{Sequence alignment and phylogenetic analysis}

The sequences were blasted in GenBank with Blastn. LSU and ITS data sets were analysed. Based on the blasts, further related sequences were assembled for each fungus. The combined data matrix was aligned using MAFFT v.7 (http://mafft.cbrc.jp/alignment/software) and manually adjusted using MEGA 6.06 to allow maximum alignment and maximum sequence similarity. A phylogenetic analysis was conducted using maximum likelihood (ML) in MEGA 6.06 (Kumar et al. 2008) with 1000 bootstrap replicates. The most suitable substitution models for the respective datasets were selected by using MEGA6.06. Tamura 3-parameter model with Gamma distribution was used in analysis. Gaps were treated as a pairwise deletion and trees were viewed with MEGA6.06. All newly generated ITS and LSU sequences used in this study are deposited in GenBank. 


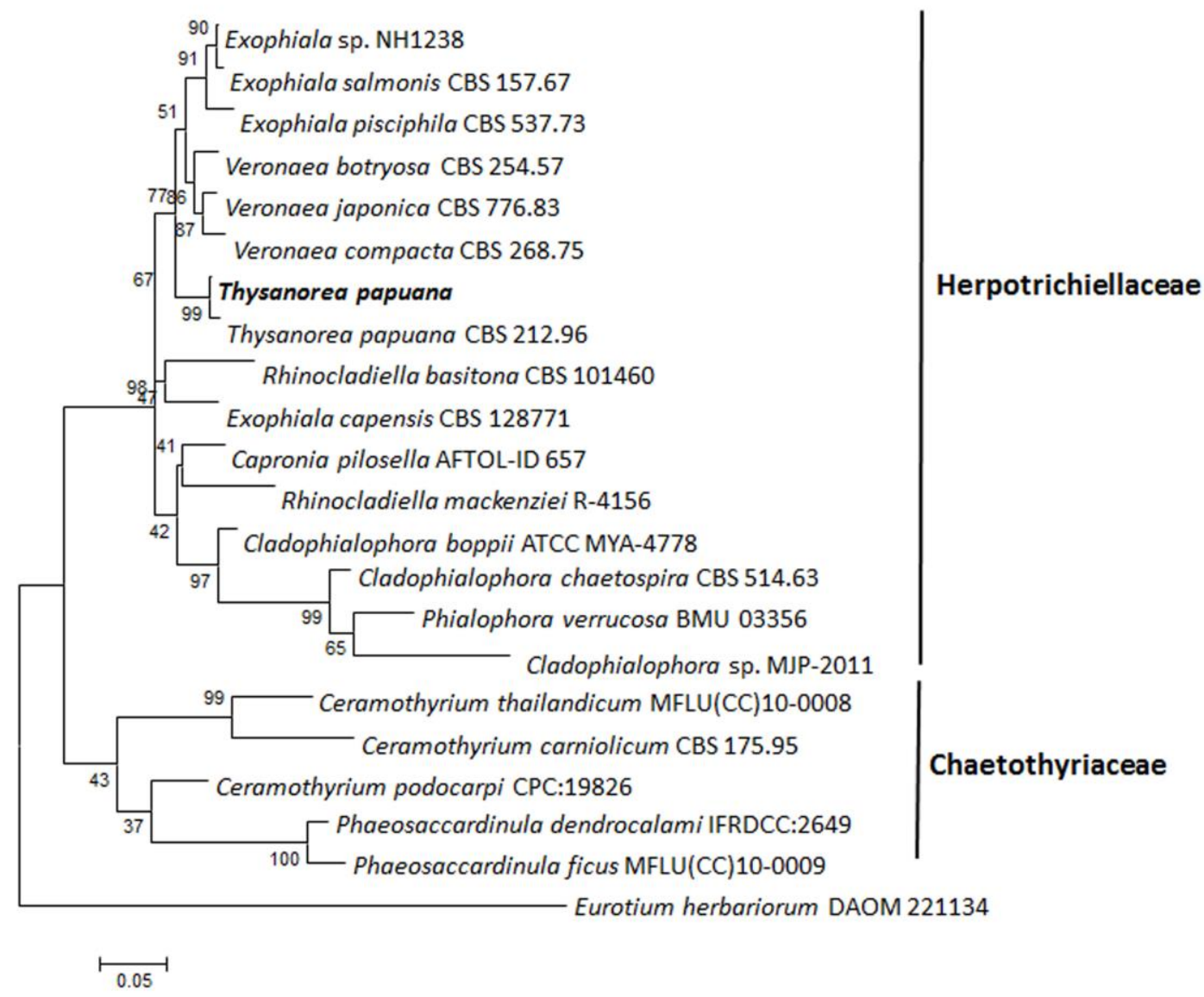

Fig. 3 - Maximum likelihood tree of Thysanorea papuana and related taxa based on combined analysis of ITS and LSU sequences. Species described in this study is in bold.

\section{Results}

\section{Taxonomy}

Thysanorea papuana (Aptroot) Arzanlou, W. Gams \& Crous, in Arzanlou, Groenewald, Gams, Braun, Shin \& Crous, Stud. Mycol. 58: 80 (2007)

Colonies on MEA effuse, flat, dark brown, reverse dark brown, with irregular margin, attaining $1 \mathrm{~cm}$ diam. in 7 days at $28^{\circ} \mathrm{C}$. Colonies on natural substrate effuse, dark brown to black, hairy. Mycelium partly immersed, partly superficial, composed of light brown, smooth, branched, thin-walled, 1.5-2 $\mu \mathrm{m}$ wide hyphae. Conidiophores macronematous, mononematous, thick-walled, septate, dark brown, smooth, $220-490 \times 4-10 \mu \mathrm{m}$, apically branched, forming a head with up to 3 levels of 30-50 $\mathrm{mm}$ long branchlets. Conidiogenous cells terminal and intercalary, thin-walled, smooth, brown at the base, paler towards the apex, 8-20 $\times 2-4 \mu \mathrm{m}$, denticulate; denticles numerous, thickened, lightly pigmented, about $1 \mu \mathrm{m}$ diam. Conidia solitary, thin-walled, smooth, pale brown, obovoid, always 1-septate, septa darkened and slightly raised at sides, $6-9 \times 2-3 \mu \mathrm{m}$, with a truncate base and darkened hilum, $1 \mu \mathrm{m}$ diam.

Specimen examined - India, Goa, Valpoi on unidentified dead twig, J. Pratibha, 26 Jan 2013, Herb. No. VTL-14. (Fig. 1, Fig. 2)

Notes - Arzanlou et al. (2007) introduced the genus Thysanorea to accommodate Periconiella papuana based on partial sequences of the 28S (LSU) rRNA gene and the ITS region (ITS1, 5.8S rDNA and ITS2) and morphological characters like complex head consisting of up to six levels of branches and having dimorphic conidiophores with more or less prominent denticlelike conidiogenous loci. This fungus was collected in current study from terrestrial litter samples. 


\section{Phylogenetic analyses}

Twenty-two taxa are included in the phylogenetic analysis (Table 1, Fig. 3). Preliminary phylogenetic analysis showed that the fungus has affinities with the genus Thysanorea. Thysanorea was introduced to accommodate Periconiella papuana (Herpotrichiellaceae), which is unrelated to P. velutina, the type species of Periconiella (Mycosphaerellaceae) (Arzanlou et al. 2007). Thus, a dataset of two families Herpotrichiellaceae and Chaetothyriaceae from order Chaetothyriales was assembled. Eurotium herbariorum (Eurotiales) was selected as the outgroup taxon. Molecularphylogeny showed that the Indian isolate is similar to the type species Thysanorea papuana with $99 \%$ bootstrap support, thus confirming its identity. This forms an interesting new record to India of a fungal genus originally reported from Papua New Guinea (Arzanlou et al. 2007).

Table 1 Origin of DNA sequences used in combined analyses of ITS and LSU. Newly deposited sequences are in bold

\begin{tabular}{llll}
\hline Taxon & Accession no. & ITS & LSU \\
\hline Capronia pilosella & AFTOL-ID 657 & DQ826737 & DQ823099 \\
Ceramothyrium carniolicum & CBS 175.95 & KC978733 & KC455251 \\
Ceramothyrium podocarpi & CPC:19826 & KC455251 & KC005795 \\
Ceramothyrium thailandicum & MFLU(CC)10-0008 & HQ895838 & HQ895835 \\
Cladophialophora boppii & ATCC MYA-4778 & JN882312 & JN874491 \\
Cladophialophora chaetospira & CBS 514.63 & KF928449 & KF928513 \\
Cladophialophora sp. & MJP-2011 & JF263533 & JF263534 \\
Eurotium herbariorum & DAOM 221134 & JN942870 & JN938918 \\
Exophiala capensis & CBS 128771 & JF499841 & JF499861 \\
Exophiala pisciphila & CBS 537.73 & AF050272 & AF361052 \\
Exophiala salmonis & CBS 157.67 & JF747137 & AY213702 \\
Exophiala sp. & NH1238 & AB488490 & AB488490 \\
Phaeosaccardinula dendrocalami & IFRDCC:2649 & KF667242 & KF667245 \\
Phaeosaccardinula ficus & MFLU(CC)10-0009 & HQ895840 & HQ895837 \\
Phialophora verrucosa & BMU 03356 & KF881928 & KJ930100 \\
Rhinocladiella basitona & CBS 101460 & EU041806 & EU041863 \\
Rhinocladiella mackenziei & R-4156 & FJ427211 & FJ427212 \\
Thysanorea papuana & GUFCC 18020 & KR259881 & KR259882 \\
Thysanorea papuana & CBS 212.96 & EU041814 & EU041871 \\
Veronaea botryosa & CBS 254.57 & EU041816 & EU041873 \\
Veronaea compacta & CBS 268.75 & EU041819 & EU041876 \\
Veronaea japonica & CBS 776.83 & EU041818 & EU041875 \\
\hline
\end{tabular}

\section{Acknowledgements}

Thanks are due to the University Grants Commission, New Delhi, for postdoctoral research grant support. We take this opportunity to thank Head of Department of Botany, Goa University and guide Prof. M.K. Janarthanam for supporting this work. AP is thankful to Head, BSI, ERC, Shillong and The Director, Botanical Survey of India for support.

\section{References}

Arzanlou M, Groenewald JZ, Gams W, Braun U, Shin HD, Crous PW. 2007 - Phylogenetic and morphotaxonomic revision of Ramichloridium and allied genera. Studies in Mycology 58, 57-93. http://dx.doi:10.3114/sim.2007.58.03

Choi YW, Hyde KD, Ho WH. 1999 - Single spore isolation of fungi. Fungal Diversity 1, 29-38.

Crous PW, Braun U, Wingfield MJ, Wood AR, Shin HD, Summerell BA, Alfenas AC, Cumagun CJ, Groenewald JZ. 2009 - Phylogeny and taxonomy of obscure genera of microfungi. Persoonia 22, 139-161. http://dx.doi: 10.3767/003158509X461701

Drummond AJ, Ashton B, Buxton S, Cheung M, Cooper A, Heled J, Kearse M, Moir R, StonesHavas S, Sturrock S, Thierer T, Wilson A. 2010 - Geneious v. 5.1, available from 
http://www.geneious.com.

Kumar S, Nei M, Dudley J, Tamura K. 2008 - MEGA: a biologist-centric software for evolutionary analysis of DNA and protein sequences. Briefings in Bioinformatics 9, 299-306.

Prabhugaonkar A, Bhat DJ. 2011 - New record of Megacapitula villosa and Paradictyoarthrinium diffractum from India. Mycosphere 2(4), 463-467.

White TJ, Bruns T, Lee S, Taylor J. 1990 - Amplification and direct sequencing of fungal ribosomal RNA genes for phylogenetics. In: Innis MA, Gelfand DH, Sninsky JJ, White TJ, (Eds.) PCR protocols: a guide to methods and applications. Academic Press, New York, USA, pp. 315-322. 